\title{
Evaluation of an HIV-Related Workshop for Adolescents at a Secondary School in Germany
}

\author{
Burt Davis $^{1} \&$ Katharina Grosser ${ }^{1}$ \\ ${ }^{1}$ Faculty of Economic and Management Sciences, Stellenbosch University, Stellenbosch, South Africa \\ Correspondence: Dr Burt Davis, Africa Centre for HIV/AIDS Management, University of Stellenbosch, Private \\ Bag X1, Stellenbosch, 7602, South Africa. Tel: 27-21-808-3006. E-mail: burt@sun.ac.za
}

Received: August 21, 2019 Accepted: October 13, 2019 Online Published: October 15, 2019

doi:10.5539/gjhs.v11n12p157 URL: https://doi.org/10.5539/gjhs.v11n12p157

\begin{abstract}
This study set out to establish to what extent an HIV-related awareness workshop involving German adolescents at a secondary school in Brandenburg can help to increase knowledge levels about this disease. Only a few studies have explored what German youths know about HIV, with none so far evaluating a workshop aimed at increasing HIV-related knowledge levels among this cohort. In a pre-test post-test design, changes in participants' knowledge levels related to the risk of HIV transmission associated with different types of exposures or behaviors such as unprotected sex, mother-to-child-transmission, blood transfusions, and shaking hands were assessed. Previous studies have shown that German youths lack knowledge in this regard.

From pre-test to post-test, there was a statistically significant increase in knowledge levels about the risk of HIV transmission. However, knowledge levels about the risk of HIV transmission was relatively low. An average of $59.2 \%$ questions were answered correctly at pre-test vs. $68.1 \%$ of questions at post-test. The present study underlines that an awareness workshop can be a useful tool to improve knowledge levels about the risk of HIV transmission among youths. However, the results also revealed that there is still some work to be done to educate young Germans about the basic facts around HIV/AIDS. Although HIV incidence rate in Germany has been slightly decreasing, there is a growing number of new infections among people who are unaware of their HIV status - while research shows that youths in this country are seemingly complacent about the danger of HIV/AIDS, and often do not use condoms during sex.
\end{abstract}

Keywords: HIV/AIDS, Germany, adolescents, HIV-related knowledge, HIV transmission

\section{Introduction}

\subsection{The Problem of HIV Among German Youths}

In Germany, about 87,000 people are currently living with HIV/AIDS (between $0.1-0.2 \%$ of the total population) (Joint United Nations Programme on HIV/AIDS [UNAIDS], 2018). HIV incidence and prevalence rates are among the lowest in Europe. However, recent World Health Organization (WHO) statistics show that the highest number of new HIV infections recorded in Europe in a single year since this organization started keeping record almost two decades ago occurred in 2016 (WHO, 2017). There has also been increase in the HIV incidence rate in Germany among people who are unaware of their HIV status since 2011 (Robert Koch Institute, 2018). Given this scenario, it may be concerning that German youths are seemingly complacent about the dangers of HIV/AIDS. A longitudinal study (1987 to 2007) conducted by the Bundeszentrale für gesundheitliche Aufklärung or BZgA (English: Federal Centre for Health Education) reports that among 16 to 20 -year-olds in 1988, 87\% said that AIDS was "the most dangerous disease in the world". In 2007, only $38 \%$ of this cohort agreed that AIDS was "still the most dangerous disease in the world" (BZgA, 2008). (Note 1) Exacerbating this worrying situation, is that another survey also conducted by the BZgA of German youths aged 14-17 year-old found that only $39 \%$ of boys and $31 \%$ of girls used a condom in their last sexual contact (BZgA, 2010). Generally, there is a reluctance among European youths to use condoms (Samkange-Zeeb, Mikolajczyk, \& Zeeb, 2012). In view of German adolescents' apparent lackadaisical attitude towards HIV/AIDS and their lack of condom use, as well as the rise of HIV incidence rates of people who are unaware of their HIV status in this country as a whole, it may be important to find out how effective HIV/AIDS interventions aimed at German youths are to help increase knowledge levels about this disease.

This paper sets out to determine to what extent an HIV-related awareness workshop presented at a German public 
school can be effective to help increase knowledge levels about this disease among participating adolescents.

\subsection{How HIV Information Is Disseminated in Germany}

Education about HIV/AIDS as well as other sexually transmitted infections (STIs) in Germany are conducted on three levels. Firstly, the BZgA, which reports to the German Federal Ministry of Health, is an expert authority that oversees the implementation of health education and national health policies in Germany as a whole. Secondly, at schools, HIV/AIDS and STIs awareness training forms part of sex education within the education system. Thirdly, the non-profit organisation German AIDS Association with its 130 partner organisations operates country-wide serving the general public (BZgA, 2017). The German AIDS Association is supported by the German AIDS Foundation and other non-governmental organisations who conduct peer education workshops at e.g. schools (BZgA, 2014a).

\subsection{HIV-Related Knowledge Studies of Adolescents and Young Adults in Germany}

Only a few studies about HIV-related knowledge levels of adolescents and young adults in Germany could be identified. In a systematic review of peer-reviewed published literature between 1990-2010 about awareness and knowledge of STIs among school-going adolescents in Europe by Samkange-Zeeb, Spallek, and Zeeb (2011), only one study was identified which was conducted in Germany. In this study by Sachsenweger, Kundt, Hauk, Lafrenz, and Stoll (2011), a survey was conducted at different schools in Mecklenburg-Western Pomerania to determine HIV-related knowledge levels. Apart from reporting on the details of the latter study, we further discuss two peer-reviewed published studies, two unpublished studies, and two national survey-type studies that conducted research about HIV-related knowledge levels among German adolescents.

The first peer-reviewed published study was by Samkange-Zeeb et al. (2012) who conducted a questionnaire-based survey to assess the knowledge and awareness of STIs levels among adolescents in eight schools in the cities of Bremen and Bremerhaven. The second peer-reviewed published study was by von Rosen, von Rosen, Müller-Riemenschneider, Damberg, and Tinnemann (2018) who determined knowledge levels of STIs including HIV/AIDS of pupils in a cross-sectional study at 13 secondary schools in Berlin. The two unpublished studies (dissertations) were by Sachsenweger (2008) and Kundrath (2016). Sachsenweger (2008) surveyed knowledge levels about well-known HIV-related facts among students at 11 schools in Mecklenburg-Western Pomerania. This study analysed the effectiveness of an HIV-related poster campaign at educational institutions by conducting a survey before and after posters were displayed. Kundrath (2016) evaluated a three hour teacher-centred lesson of STIs including HIV/AIDS of young people/students at the Ludwig Maximilian University in Munich at three different time intervals over a three month period. The two national survey-type studies we identified were conducted by BZgA i.e. the already mentioned longitudinal study which ran annually from 1987-2007 (we report on the 2007 findings with the findings dated 2008) as well as a further study reported on in 2014. Both these surveys measured, among other, HIV-related knowledge levels. See Table 1 for the main findings related to the HIV knowledge questions from the studies mentioned above. (Note 2)

Table 1. Main findings of HIV-related prevention knowledge studies conducted among adolescents and young adults in Germany (average percentage of questions answered correctly)

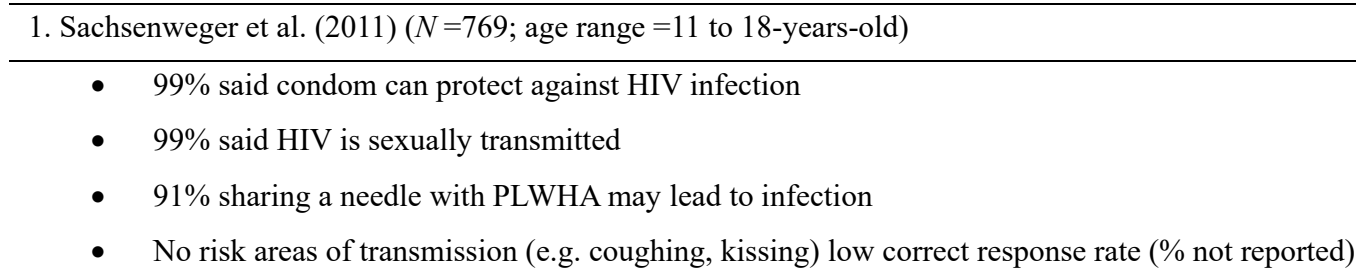

2. Samkange-Zeeb et al. (2012) $(N=1148$; age range $=12$ to 20 -year-old $)$

- $94 \%$ said a condom is a form of STI prevention

- $\quad$ There is no HIV-vaccine (\% not reported)

3. von Rosen et al. (2018) $(N=1177$; age range $=13$ to 16 -year-old $)$

- $\quad 63.2 \%$ said there was no HIV-vaccine

- $\quad 83.6 \%$ said HIV was not curable 
4. Sachsenweger (2008) ( $2^{\text {nd }}$ survey: $N=803$; age range $=11$ to 18 -year-old $)$

- $\quad 99 \%$ said unprotected sexual intercourse with unknown people as a risk of HIV infection

- $\quad 88 \%$ said HIV is not transmitted through coughing or inhaling

- $81 \%$ said HIV is not transmitted through kissing

- $\quad 82 \%$ HIV can be transmitted through bleeding wounds

- $\quad 91 \%$ HIV can be transmitted by drug injection using needles

- $\quad 63 \%$ HIV can be transmitted through small skin scratches

5. Kundrath (2016) $(N=1763$; age range $=11$ to 27 -year-old $)$

- $\quad 97 \%$ (pre) and 99\% (post) intervention said that a condom was effective in HIV prevention

- $\quad 31 \%$ (pre) and 93\% (post) knew that breast milk was a risk factor of HIV infection

6. BZgA (2008) survey ( $N=1997$; age range $=16$ to 20 -years-old $)$

- $100 \%$ said unprotected sexual intercourse with unknown people is a risk of HIV infection

- $\quad 99 \%$ said to share needles/drug consumption is a risk of HIV infection

- $\quad 97 \%$ said to shake hands with PLWHA has no risk of HIV infection

- $\quad 90 \%$ said treatment by a doctor who treated HIV/AIDS patients has no risk of HIV infection

- $63 \%$ said infection with HIV-positive blood has a risk of HIV infection

7. $\mathrm{BZgA}(2014 \mathrm{~b})$ survey $(N=1,002$; age range $>16$ years old $)$

- $\quad 99 \%$ stated unprotected sexual intercourse with unknown people as a risk of HIV infection

- $\quad 99 \%$ stated to share needles/drug consumption as a risk of HIV infection

- $\quad 99 \%$ stated infection with HIV-positive blood as a risk of HIV infection

- $\quad 97 \%$ stated to shake hands with PLWHA as no risk of HIV infection

- $94 \%$ stated to work together with PLWHA as no risk of HIV infection

- $88 \%$ stated treatment by a doctor who treated HIV/AIDS patients as no risk of HIV infection

Overall, as can be seen in Table 1, knowledge about basic aspects of HIV were tested across the different studies. Knowledge levels were generally high across all studies. This finding is similar to what Samkange-Zeeb et al. (2011) report in their systematic review about HIV knowledge levels among school-going adolescents in Europe. However, some of the studies we report on show only moderately high knowledge levels for certain aspects of HIV, with these mostly having to do with the risk of HIV transmission associated with different types of exposures or behaviors. That is, moderately high knowledge levels were found in the studies by 1) the BZgA (2008) related to HIV-infection from contaminated blood, and 2) Sachsenweger et al. (2011) and Sachsenweger (2008) related to the risk of transmission through e.g. coughing, kissing, and scratches. In addition, the study by Kundrath (2016) report low knowledge levels related to HIV transmission through breast milk (pre-intervention).

In summary, only a few studies have been done to determine knowledge levels about HIV among youths in a German context. These studies generally focussed on trying to find out what participants know about the basic facts around HIV/AIDS. Although participants displayed generally high knowledge levels across the board, some participants lacked specific knowledge about the risk of HIV transmission associated with different types of exposures or behaviors. Moreover, to the best of our knowledge, no study so far has evaluated an HIV-related awareness workshop for German adolescents as proposed in the current study.

\section{Method}

The current study evaluated an HIV-related awareness workshop for German youths at a secondary school in the federal state of Brandenburg in a pre-test-post-test design (Christensen, Johnson, \& Turner, 2015). We decided to focus exclusively on assessing changes in participants' knowledge levels about the risk of HIV transmission, given that previous studies have shown German youths to lack knowledge in this regard (as discussed in Section 1 of this article). The awareness workshop in question was presented by a German youth AIDS association. 


\subsection{Participants}

To select a specific secondary school, the researchers liaised with the German youth AIDS association who proposed a suitable educational institution in Brandenburg. There were no preferences or criteria for the specific school selected. Age levels for secondary schools differ across German federal states. In Brandenburg, it is 13 (turning 14) to 18 (turning 19). The selected sample comprised 57 pupils of 13 to 14-year-old German speaking male and female youths of Grade 8 level with no cognitive challenges. Of the sample, 22 participants were male $(38.6 \%)$ and 35 female $(61.4 \%)$; 31 participants were 13 years old $(54.4 \%)$ and 26 participants were 14 years old $(45.6 \%)$. The participants' mean age was 13.46 years $(S D=.50)$.

\subsection{Measures}

An 11-item questionnaire was developed for the study based on questions used by the BZgA in their longitudinal study conducted between 1987 and 2007 (BZgA, 2008). The questionnaire's items and answers were discussed with and approved by the workshop presenters. Information related to the items in the questionnaire was disseminated during the workshop presentation.

\subsubsection{Knowledge Scale About the Risk of HIV Transmission}

A knowledge scale about the risk of HIV transmission was created for this study, with 11 items assessing the facts about the risk of HIV transmission associated with different types of exposures or behaviors that were conveyed during the workshop (see below). The risk classification of getting HIV in the different scenarios was based on the estimated per-act probability of acquiring HIV as proposed by the Centers for Disease Control and Prevention (CDC, 2019) and UNAIDS (1999). The risk of HIV infection was classified as either being high risk, low risk or no/negligible risk. Each answer was scored as $1=$ correct or $0=$ incorrect (no answer was also regarded as incorrect). Scores could range from 0 to 11 . See Table 2.

\subsection{Procedure}

The parents of the selected adolescents were firstly asked to complete parental consent forms prior to the intervention. Parental consent forms were sent to the head teacher of the selected classes who passed the forms on to the adolescents four weeks before the workshop. The workshop took place during school periods and was part of the school curriculum (sex education). The adolescents were asked to return the signed parental consent forms to the head teacher. On the day of the intervention, all ethical issues were explained by the researchers and assent forms were completed first. Next, the questionnaire was completed before participants were exposed to the awareness workshop. Participants were asked to complete the same questionnaire again immediately after the workshop. All procedures were conducted in German. This study was approved by the Social, Behavioural, and Education Ethics Committee of Stellenbosch University in South Africa. (Note 3) Although domestic ethical clearance was not officially required for this study (Education Act Federal State of Brandenburg, 2007; Federal Association of German Market and Social Researchers, 2006), the local school board did give permission for it to be conducted.

\section{Results}

\subsection{Recruitment}

Parental consent forms were sent out in February 2018, which gave the parents four weeks to decide about their child's participation in the study and workshop. The workshop and study were conducted on 20 March 2018.

\subsection{Statistics and Data Analysis}

Frequencies, means and percentages were computed to describe the sample. Pre-test and post-test scores on knowledge about the risk of HIV transmission were compared with a paired t-test. 
Table 2. Numbers and percentages for the correct responses at pre-test vs. post-test of the 11 items making up the knowledge scale about the risk of HIV transmission

\begin{tabular}{|c|c|c|c|}
\hline Items & $\begin{array}{l}\text { Pre-test } \\
(N=57)\end{array}$ & $\begin{array}{l}\text { Post-test } \\
(N=57)\end{array}$ & $\begin{array}{l}\text { Change in HIV-related } \\
\text { knowledge level }\end{array}$ \\
\hline $\begin{array}{l}\text { 1. If you are treated by a doctor who also treats HIV/AIDS patients. } \\
\text { (Correct answer: No risk) }\end{array}$ & $\begin{array}{l}63.2 \% \\
(36)\end{array}$ & $\begin{array}{l}68.4 \% \\
(39)\end{array}$ & $+5.2 \%$ \\
\hline $\begin{array}{l}\text { 2. If you do not use a condom when you have sex with someone whose } \\
\text { HIV-status you do not know. } \\
\text { (Correct answer: high risk) }\end{array}$ & $\begin{array}{l}84.2 \% \\
(48)\end{array}$ & $\begin{array}{l}93 \% \\
(53)\end{array}$ & $+8.8 \%$ \\
\hline $\begin{array}{l}\text { 3. If you shake hands with someone who has HIV/AIDS. } \\
\text { (Correct answer: No risk) }\end{array}$ & $\begin{array}{l}82.5 \% \\
(47)\end{array}$ & $\begin{array}{l}89.5 \% \\
(51)\end{array}$ & $+7 \%$ \\
\hline $\begin{array}{l}\text { 4. If two guys/men have anal intercourse. } \\
\text { (Correct answer: high risk) }\end{array}$ & $\begin{array}{l}45.6 \% \\
(26)\end{array}$ & $\begin{array}{l}77.2 \% \\
(44)\end{array}$ & $+31.6 \%$ \\
\hline $\begin{array}{l}\text { 5. If you give someone a blowjob (oral intercourse). } \\
\text { (Correct answer: low risk) }\end{array}$ & $\begin{array}{l}19.3 \% \\
(11)\end{array}$ & $\begin{array}{l}14 \% \\
(8)\end{array}$ & $-5.3 \%$ \\
\hline $\begin{array}{l}\text { 6. If razor blades are being shared among a number of people and have } \\
\text { not been disinfected. } \\
\text { (Correct answer: high risk) }\end{array}$ & $\begin{array}{l}24.6 \% \\
(14)\end{array}$ & $\begin{array}{l}24.6 \% \\
(14)\end{array}$ & $0 \%$ \\
\hline $\begin{array}{l}\text { 7. If someone has another STI (e.g. chlamydia) in addition to HIV and } \\
\text { does not use a condom when having sex with another person. } \\
\text { (Correct answer: high risk) }\end{array}$ & $\begin{array}{l}91.2 \% \\
(52)\end{array}$ & $\begin{array}{l}91.2 \% \\
(52)\end{array}$ & $0 \%$ \\
\hline $\begin{array}{l}\text { 8. If someone injects drugs and uses needles that have been used by } \\
\text { other people before. } \\
\text { (Correct answer: high risk) }\end{array}$ & $\begin{array}{l}68.4 \% \\
(39)\end{array}$ & $\begin{array}{l}87.7 \% \\
(50)\end{array}$ & $+19.3 \%$ \\
\hline $\begin{array}{l}\text { 9. When an HIV-positive woman gives birth, her baby could become } \\
\text { HIV-positive during birth. } \\
\text { (Correct answer: high risk) }\end{array}$ & $\begin{array}{l}47.4 \% \\
(27)\end{array}$ & $\begin{array}{l}50.9 \% \\
(29)\end{array}$ & $+3.5 \%$ \\
\hline $\begin{array}{l}\text { 10. If you receive a blood transfusion not screened for HIV. } \\
\text { (Correct answer: high risk) }\end{array}$ & $\begin{array}{l}77.2 \% \\
(44)\end{array}$ & $\begin{array}{l}87.7 \% \\
(50)\end{array}$ & $+10.5 \%$ \\
\hline $\begin{array}{l}\text { 11. When you use a public toilet. } \\
\text { (Correct answer: no risk) }\end{array}$ & $\begin{array}{l}47.4 \% \\
(27)\end{array}$ & $\begin{array}{l}64.9 \% \\
(37)\end{array}$ & $+17.2 \%$ \\
\hline Total & $\begin{array}{l}59.2 \% \\
(371)\end{array}$ & $\begin{array}{l}68.1 \% \\
(427)\end{array}$ & $+8.9 \%$ \\
\hline
\end{tabular}

As Table 2 shows, there was an overall positive knowledge gain of $8.9 \%$ from pre-test to post-test. Positive knowledge gain pre-test vs post-test was found for 8 out of 11 items (Items 1-4; and Items 9-11), while two items remained unchanged (Items 6 and Item 7) and one item showed a decrease (Item 5). Items 5 and 6 had very low knowledge levels at both pre-test and post-test $(<25 \%$ correct responses).

Next, a paired-sample t-test was conducted to test the effect of the awareness workshop. This test was deemed the most fitting test to use as we wanted to compare mean scores involving the dependent variable (knowledge about the risk of HIV transmission) pre vs. post intervention (awareness workshop i.e. the independent variable) (Field, 2009, p.325). A significant difference was found in the scores for knowledge about the risk of HIV transmission at pre-test $(M=6.51, S D=1.61)$ compared to post-test $(M=7.49, S D=1.44) ; t=-3.72, p<.001)$.

\section{Discussion}

This study set out to establish to what extent an HIV-related awareness workshop can be effective to increase knowledge levels about the risk of HIV transmission. The workshop was aimed at adolescents and presented by an independent association at a secondary school in Brandenburg, Germany. Only a few studies have been done to 
determine knowledge levels about HIV among youths in a German context, with none so far evaluating a workshop aimed at increasing HIV-related knowledge levels among this cohort. This may be important, as HIV incidence rates among people who are unaware of their HIV status in Germany have been rising since 2011, while studies show that German youths are seemingly complacent about the danger of HIV/AIDS and often do not use condoms during sex (Robert Koch Institute, 2018; BZgA, 2008).

In a pre-test post-test design, main findings showed that there was a significant difference in the scores for knowledge about the risk of HIV transmission at pre-test compared to the post-test conditions, with a clear knowledge gain post-intervention. For 8 out of 11 items which made up the knowledge scale about the risk of HIV transmission there was a positive knowledge gain post-test, while two items remained unchanged and for one item there was a net loss.

Despite the effectiveness of the workshop as a whole, knowledge levels about the risk of HIV transmission was relatively low, with an average of $59.2 \%$ questions answered correctly pre-test and $68.1 \%$ of questions answered correctly post-test. This finding is comparable to the results of studies by the BZgA (2008), Sachsenweger et al. (2011), Sachsenweger (2008) and Kundrath (2016), who reported low to moderately high knowledge levels related to the risk of HIV transmission. In the current study, especially Item 5 "If you give someone a blowjob (oral intercourse)" and Item 6 "If razor blades are being shared among a number of people and have not been disinfected" were poorly answered at both pre-test and post-test. A possible reason for the low knowledge levels in this regard may be explained by the classification used to describe the risk of HIV transmission in the different scenarios making up the items in the questionnaire i.e. high risk, low risk, and no risk. This classification may perhaps have been challenging for participants to understand and/or remember given their youthfulness. The participants' mean age was 13.46 years $(S D=.50)$. A dichotomous scale using anchors such as "risk" or "no risk" may have perhaps yielded better results. Another possible explanation may relate to what extent the relevant information was communicated during the workshop itself, as well as the correctness thereof. As mentioned, the questionnaire content and suggested answers were discussed with and approved by the workshop presenters prior to the workshop. The researchers were also assured that all the relevant information in the questionnaire would be included in the workshop's curriculum and disseminated on the day of the presentation.

This study was not without its limitations. This research was a small-scale study conducted at one educational institution, which possibly limits the generalizability of the results. Similar studies at a variety of schools including secondary schools, comprehensive schools and middle schools across different federal states would be preferable. Another limitation was the fact that different parts of the workshop were presented by three different peer educators which could have affected the results of this study. However, the German youth AIDS association made sure that all the peer educators involved with the workshop received the same in-house training and were instructed to use exactly the same content during the workshop.

In conclusion, this study underlines that an awareness workshop can be a useful tool to help improve knowledge levels related to HIV/AIDS among German adolescents. However, the results also revealed that there is still some work to be done to educate young people about the facts around HIV/AIDS, especially pertaining to the risk of HIV transmission involved with different types of exposures or behaviors. This may be important given the rising levels of HIV incidence among people in Germany who are unaware of being HIV-positive, as well as HIV incidence rates in Europe as a whole over the last few years (Robert Koch Institute, 2018; WHO, 2017).

\section{Acknowledgements}

We thank all the respondents who took time to participate in this study. Without their participation this study would not have been possible. We also thank the school principal and their local school board for allowing us to conduct our research at this institution as well as a German youth AIDS association for facilitating and identifying a suitable school and evaluating their workshop.

\section{Competing Interest Statement}

The authors declare that there is no conflict of interest.

\section{References}

Aaro, L., Breivik, K., Klepp, K.-I., Kaaya, S., Onya, H., Wubs, A., ... Flisher, A. (2011). An HIV/AIDS knowledge scale for adolescents: item response theory analyses based on data from a study in South Africa and Tanzania. Health Education Research, 26(2), 212-224. https://doi.org/10.1093/her/cyq086

Becker, M. (2011, June 1). Zwei Millionen Teenager mit Aids-Erreger infiziert [Two million teenagers infected with AIDS virus]. $\quad$ Der $\quad$ Spiegel. $\quad$ Retrieved from 
http://www.spiegel.de/wissenschaft/medizin/unicef-bericht-zwei-millionen-teenager-mit-aids-erreger-infizie rt-a-766121.html

Bundeszentrale für gesundheitliche Aufklärung (BZgA) [Federal Centre for Health Education]. (2008). AIDS im Öffentlichen Bewusstsein der Bundesrepublik Deutschland 2007 [AIDS in the Public Consciousness of the Federal Republic of Germany 2007]. (BZgA publication). Retrieved from https:/www.bzga.de/fileadmin/user_upload/PDF/studien/aids_2008_k--292c0271a5bd4156b1a7ecd86c413 171.pdf

Bundeszentrale für gesundheitliche Aufklärung (BZgA) [Federal Centre for Health Education]. (2010). Youth Sexuality 2010: Repeat Survey of 14 to 17-year-olds and their parents. (BZgA Publication). Retrieved from https:/www.bzga.de/infomaterialien/sexualaufklaerung/studien/youth-sexuality-2010/

Bundeszentrale für gesundheitliche Aufklärung (BZgA) [Federal Centre for Health Education]. (2014a). HIV/AIDS von A bis Z - Heutiger Wissensstand [HIV/AIDS from A to Z - Current state of knowledge]. (BZgA publication). Retrieved

from https://www.aidshilfe.de/sites/default/files/documents/Heutiger\%20\%20Wissensstand.pdf

Bundeszentrale für gesundheitliche Aufklärung (BZgA) [Federal Centre for Health Education]. (2014b). Wissen und Einstellung der Bevölkerung zu den Infektionsrisiken mit HIV im Alltag [Knowledge and attitudes of the population to the risks of HIV infection in everyday life]. (BZgA publication). Retrieved from https://www.liebesleben.de/media/presse/mediathek/factsheet_infografik/Wissen_Einstellungen_Bevoelker ung_HIV_Welt-AIDS-Tag_2014.pdf

Bundeszentrale für gesundheitliche Aufklärung (BZgA) [Federal Centre for Health Education]. (2017). Tasks and Goals. Retrieved 18 August 2019, from https://www.bzga.de/home/bzga/tasks-and-goals/

Centers for Disease Control and Prevention (CDC). (2019). HIV Risk Behaviors. Retrieved 18 August 2019, from https://www.cdc.gov/hiv/risk/estimates/riskbehaviors.html

Christensen, L. B., Johnson, R. B., \& Turner, L. A. (2015). Research Methods, Design, and Analysis (12th ed.). Boston, MA: Pearson.

Education Act Federal State of Brandenburg. (2007). Brandenburgisches Schulgesetz [Brandenburg School Act]. Retrieved 18 August 2019, from http://www.andersartig.info/files/brandenburg-schulgesetz.pdf

Federal Association of German Market and Social Researchers. (2006). Richtlinie für die Befragung von Minderjährigen [Guidelines for interviewing minors]. Retrieved 18 August 2019, from https:/www.rat-marktforschung.de/fileadmin/user_upload/pdf/R05_RDMS.pdf

Field, A. (2009). Discovering statistics using SPSS (3rd ed.). London: Sage.

Goodwin, R., Kozlova, A., Nizharadze, G., \& Polyakova, G. (2004). HIV/AIDS among adolescents in Eastern Europe: Knowledge of HIV/AIDS, social representation of risk and sexual activity among school children and homeless adolescents in Russia, Georgia and the Ukraine. Journal of Health Psychology, 9(3), 381-396. https://doi.org/10.1177\%2F1359105304042348

Joint United Nations Programme on HIV/AIDS (UNAIDS). (1999). Prevention of HIV transmission from mother to child: Strategic options (UNAIDS publication). Retrieved from https://www.unaids.org/sites/default/files/media_asset/prevention_en_0.pdf

Kundrath, K. (2016). Frontalunterricht - eine unterschätzte Alternative für die HIV/STI-Prävention bei Jugendlichen. Eine Studie zur Effektivität einer außerschulischen Präventionsmaßnahme im Setting Hörsaal [Frontal education - an underestimated alternative to HIV/STI prevention in adolescents. A study on the effectiveness of an extracurricular prevention measure in a lecture hall setting]. (Doctoral dissertation). Retrieved from https://edoc.ub.uni-muenchen.de/19404/1/Kundrath_Kai.pdf

Macek, M., \& Matkovic, V. (2005). Attitudes of School Environment towards Integration of HIV-Positive Pupils into Regular Classes and Knowledge about HIV/AIDS: Cross-sectional Study. Croatian Medical Journal, 46(2), 320-325.

Miller, C., Nkala, B., Closson, K., Chia, J., Cui, Z., Palmer, A., Hogg, R., Kaida, A., Gray, G., \& Dietrich, J. (2017). The Botsha Bophelo Adolescent Health Study: A profile of adolescents in Soweto, South Africa. Southern African Journal of HIV Medicine, 18(1), 1- 10. https://doi.org/10.4102/sajhivmed.v18i1.731

Robert Koch Institute. (2018). Schätzung der Zahl der HIV-Neuinfektionen und der Gesamtzahl von Menschen mit HIV in Deutschland [Estimating the number of new HIV infections and the total number of people living 
with HIV in Germany]. Epidemiologisches Bulletin, 47(2018), 509-522.

Sachsenweger, M. (2008). Der Wissensstand von Schülern über das Thema HIV/AIDS in Mecklenburg-Vorpommern und die Auswirkung einer Präventionskampagne mit Postern [The state of knowledge of students about HIV/AIDS in Mecklenburg-Western Pomerania and the impact of a prevention campaign with posters]. (Doctoral dissertation). Retrieved from https://d-nb.info/1005832609/34

Sachsenweger, M., Kundt, G., Hauk, G., Lafrenz, M., \& Stoll, R. (2011). Der Wissensstand von Schülern über das Thema HIV/AIDS an ausgewählten Schulen in Mecklenburg-Vorpommern [The state of HIV/AIDS knowledge of students in selected schools in Mecklenburg-Western Pomerania]. Gesundheitswesen, 73(1), e21-e26. https://doi.org/10.1055/s-0029-1246199

Samkange-Zeeb, F. (2013). Assessing knowledge and awareness of sexually transmitted infections among school-going adolescents (Doctoral dissertation). $\quad$ Retrieved from https://elib.suub.uni-bremen.de/edocs/00103368-1.pdf

Samkange-Zeeb, F., Mikolajczyk, R., \& Zeeb, H. (2012). Awareness and knowledge of Sexually Transmitted Diseases (STDs) among secondary school students in two German cities. J Community Health, 38(2), 293-300. https://doi.org/10.1007/s10900-012-9614-4

Samkange-Zeeb, F., Spallek, L., \& Zeeb, H. (2011). Knowledge and awareness of sexually transmitted diseases among European adolescents: a systematic review. BMC Public Health, 11, 727. https://doi.org/10.1186/1471-2458-11-727

Santos-Hövener, C., Marcus, U., Koschollek, C., Oudini, H., Wiebe, M., Ouedraogo, O.I., ... Krause, G. (2015). Determinants of HIV, viral hepatitis and STI prevention needs among African migrants in Germany; a cross-sectional survey on knowledge, attitudes, behaviors and practices. BMC Public Health, 15, 753. https://doi.org/10.1186/s12889-015-2098-2

Thomson, C., Currie, C., Todd, J., \& Elton, R. (1999). Changes in HIV/AIDS education, knowledge and attitudes among Scottish 15-16 year olds, 1990-1994: findings from the WHO: Health Behaviour in School-aged Children Study (HBSC). Health Education Research, 14(3), 357-370. https://doi.org/10.1093/her/14.3.357

Von Rosen, F. T., von Rosen, A. J., Müller-Riemenschneider, F., Damberg, I., \& Tinnemann, P. (2018). STI Knowledge in Berlin Adolescents. International Journal of Environmental Research and Public Health, 15(1), 110. https://doi.org/10.3390/ijerph15010110

World Health Organization [WHO]. (2017). HIV/AIDS surveillance in Europe 2017 (WHO publication). Retrieved from http://www.euro.who.int/_data/assets/pdf_file/0007/355570/20171127-Annual_HIV_Report.pdf

\section{Notes}

Note 1. Although prevalence of STIs among adolescents in Germany is not fully known (Samkange-Zeeb, 2013), it is estimated that among 15 to 24-year-olds, about 1,300 female and 4,300 male adolescents and young adults are HIV-positive in this country (Becker, 2011).

Note 2. For comparable studies conducted elsewhere, see Aaro et al. (2011), Goodwin, Kozlova, Nizharadze, and Polyakova (2004), Macek and Matkovic (2005), Miller et al. (2017), and Thomson, Currie, Todd, and Elton (1999).

Note 3. Although this study was conducted in Germany, the researchers were affiliated with the University of Stellenbosch in South Africa at the time of the study.

\section{Copyrights}

Copyright for this article is retained by the author(s), with first publication rights granted to the journal.

This is an open-access article distributed under the terms and conditions of the Creative Commons Attribution license (http://creativecommons.org/licenses/by/4.0/). 